\title{
Synergy between Internet Technology and Traditional Media: A Perspective on Indian Marketers
}

\author{
Meghna Rishi \\ Institute for International Management Technology, Gurgaon, India
}

\begin{abstract}
There has been limited research in the Indian Internet advertising space and this paper explores the media preferences of Indian marketers highlighting their attitude towards the new medium. Since Internet penetration is rising in India, the research also identifies whether advertisers prefer a synergy between the traditional mediums and Internet Technology for their advertising campaigns. The paper is based on empirical research conducted amongst 69 Indian marketers/advertisers belonging to New Delhi and Mumbai (India) and 50 Indian advertising/ online agency professionals. Advertisers have been chosen from industry verticals including Banking and Financial Institutions, Automobile, Fast Moving Consumer Durables (FMCG) and Telecom because they include the top advertising spenders in India (KPMG and FICCI, 2010). Views from advertising agency professionals, published in trade magazines, are considered to further substantiate the research findings through industry inputs. Based on some unique strengths of Internet advertising, Indian marketers respond positively towards including Internet in the media mix and believe in drawing synergy between Internet and traditional mediums. However they are still apprehensive about the efficacy of the medium. Indian advertising agency professionals consider it important to include Internet in the media mix, however they do not push the medium aggressively. The study identifies that Indian marketers and advertisers prefer to use Internet Technology and web advertising, in a campaign's media mix only when the campaign is also run on traditional mediums. In seclusion, the medium is not the preferred choice for advertising. The paper pinpoints the reasons for the slow acceptability of Internet advertising amongst Indian marketers and suggests learning of advertising agency professionals to leverage maximum benefit out this interactive medium. The paper also offers insight to academicians who wish to explore the changing dimensions in communication management
\end{abstract}

Keywords: Internet advertising, Indian advertising, Traditional medium, Technology, Indian Media preferences.

\section{INTRODUCTION}

I

nternet technology added itself as a component of the entertainment and media industry in early 1990's and after 20 years of the medium's inception, it is slowly moving to become a "customary institution" (Leckenby, 2005) of the society. The medium has introduced the concept of interactive communication giving consumers dual liberty of, first deciding how, when and where must they receive the advertising message and also generate content themselves which marketers can use as a platform to further

Journal of Technology Management for Growing Economies Vol. 2 No. 1 April 2011 pp. $89-101$

\section{CHITKARA IJNTERSTTY}

(C)2011 by Chitkara University. All Rights Reserved. 
Rishi, M. advertise on (An instance is blogs and forums). Globally as well as in India, Internet penetration figures have witnessed phenomenal escalation. Globally the user growth percentage of Internet has been $445 \%$ for the period 2000- 2010 while in India; the medium's users have grown by 1520 $\%$ in the mentioned period. Today, Internet users in the country are around 81 million and with around 7\% penetration (Internet World Stats, 2010) ${ }^{\mathrm{A}}$, Internet is garnering the interest of marketers and consumers rapidly, thereby impacting the marketing related decision-making of companies and businesses ( Fam et al.,2007). This penetration percentage is not very robust but keeping in mind, the year on year growth in these figures, advertisers are enticed by the potential of this interactive medium. Observing international trends brings out that India's Internet space and web advertising are fast following the global growth curve. In the United States too, Internet advertising secured its place slowly. Initially, the medium was considered apt to advertise about computers and related products. In the year 1996(Q3), computer related products, in the USA, contributed $22 \%$ to the Internet advertising revenues, web associated products contributed $32 \%$ and the share of consumer products was $12 \%$ (Meeker, 1997). In the year 2010, however the medium reached $50.3 \%$ of the US citizens (Internet World Stats, 2010) B and contributed USD 12.1 billion in the first six months of 2010( PWC and IAB, 2010).

Since the digital movement has stirred a wave of convergence amongst traditional media like television, print, radio with the new, technology driven media like Internet and mobile phones, advertising, too, has moved beyond being a jargon towards a sophisticated process where all products and services are aiming to become brands, all brands are aiming for higher customer loyalty points, all customers are flooded with innumerable choices being communicated through media and all media vehicles are aiming towards achieving higher and higher ad sales revenues. In this backdrop, Internet advertising is obviously experiencing growth and it stood at a figure of INR 3250 million in 2008- 2009 growing by $38 \%$ since the previous year, on- looking a projected growth to INR 4300 by the end of 2010 ( IAMAI, 2009). Considering the swift increase in advertising revenue from Internet, in India, this paper explores whether the medium is preferred by marketers in synergy with the established traditional media and identifies the acceptability of advertising on Internet without including any other medium in campaign's media mix.

\section{METHODOLOGY}

The paper is based on empirical research conducted amongst 119 respondents, chosen through convenience sampling technique, from the 
national capital of India, New Delhi and the financial capital of India, Mumbai. Amongst the sample, 69 respondents are marketers and advertisers from eminent organizations belonging to industry verticals including Banking and Financial Institutions, Automobile, Fast Moving Consumer Durables (FMCG) and Telecom because they are the top advertising spenders in India (KPMG and FICCI, 2010). 50 respondents are from advertising agencies and online agencies in New Delhi and Mumbai. Advertising agency professionals were included as a part of the sample population because they plan the media mix for various marketers and their belief in the efficacy of a medium trickles down as trust towards the medium, within the advertiser community. The data has been collected through a questionnaire which went through two iterations and has been authenticated by 3 marketers and 2 agency professionals. Industry verbatim from advertising agency professionals, published in leading trade magazine 'Pitch', has been considered to further authenticate the research findings. Data analysis has been done through ranking method and percentage calculations. Only the first rank given by respondents has been considered for the study as it indicates the sample's strongest preferences of media mix. The questionnaire aimed at identifying the preferred media mix combinations of Indian marketers by making the population rank the choices considering how helpful the combination will be, in attracting more eyeballs and interest, of the target market, towards the brand/ product or service. Aspects like key reasons for apprehension towards the Internet have also been explored through the current research. The entire process has led to implementable recommendations making the study useful for marketers, advertising agency professionals as well as the academia.

\section{INTERNET DEMOGRAPHICS AND WEB ADVERTISING}

Internet as a medium of communication has gained popularity based on its unique power to facilitate communication, transactions and distribution (Li and Leckenby, 2004). Since the year 2005 Internet advertising has slowly, yet steadily, started to make a place for itself in the media-mix options. Revenue growth for Internet advertising became a global phenomenon in 2005 as Asia, Europe as well as the United States witnessed marketers' inclination towards the medium. Back then (in 2005), Asia witnessed $42 \%$ growth in Internet advertising, Europe had a 31\% growth and for the US, the figure stood at 10\%. (Hoy and Lwin, 2008). After 5 years, in 2010, the trend remains similar and it is forecasted that, just like UK, in other world regions too, online medium will take over television. Further the shift of advertising budgets towards Internet got heightened in

Journal of Technology Management for Growing Economies, Volume 2, Number 1, April 2011
Synergy between Internet Technology

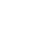

西

$\overline{2}$


Rishi, M.

growing economies like India, China and Brazil due to the Global Economic Meltdown (Schweizer, 2010).

Internet advertising is garnering the interest of Indian advertisers for varied reasons, some key ones being that the advertising cost on Internet is lesser than other traditional mediums like TV and print (Ling et al., 1999; Fam et al., 2007) and the user base of the medium holds purchasing power since they belong to top 8 metros and small towns (IAMAI and IMRB International, 2007). Ling et al., (1999) also bring forth in their research that Internet advertising is beneficial for companies with small budgets as it facilitates the process of advertising about products/ services, when the company is expanding it's existing market. The study anticipates that advertising on the web will gain further momentum when marketers would observe more and more competitors advertising on the Internet and eventually, absence from the Internet space would be considered fatal for the businesses of marketers. Web advertising would hence, gain increased acceptability and the perceived risk linked with spending advertising budget on Internet, would gradually decrease motivating the "risk-averse firms" to use the Internet Technology towards leveraging their business. Since advertisers choose a particular medium only when they are certain that the medium reaches a large number of the advertiser's target audience (Pashupati and Lee, 2003), it is important to consider the penetration figures of Internet in India and decipher the status of the medium's acceptability within the Indian marketers' community. On the macro level, analysis, of penetration of the medium and it's impact on the advertising industry is conducted through comparisons between users of Internet in Asia and the World with India.

Table 1: Users of Internet in Asia and the World

\begin{tabular}{|l|l|l|l|l|l|}
\hline $\begin{array}{l}\text { Asia } \\
\text { Region }\end{array}$ & $\begin{array}{l}\text { Population } \\
(2010)\end{array}$ & $\begin{array}{l}\text { Percentage } \\
\text { population of } \\
\text { the world }\end{array}$ & $\begin{array}{l}\text { Internet Users Till } \\
\text { June 2010 }\end{array}$ & $\begin{array}{l}\text { Penetration of } \\
\text { Internet( } \\
\text { population })\end{array}$ & $\begin{array}{l}\text { Users' } \\
\text { percentage } \\
\text { of the world }\end{array}$ \\
\hline $\begin{array}{l}\text { Asia } \\
\text { Only }\end{array}$ & $3,83,47,92,852$ & $56.02 \%$ & $82,50,94,396$ & $21.50 \%$ & $42.00 \%$ \\
\hline $\begin{array}{l}\text { Rest of } \\
\text { the } \\
\text { world }\end{array}$ & $3,01,08,17,108$ & $43.98 \%$ & $1,14,14,20,420$ & $37.91 \%$ & $58.00 \%$ \\
\hline $\begin{array}{l}\text { WORLD } \\
\text { TOTAL }\end{array}$ & $6,84,56,09,960$ & $100.00 \%$ & $1,96,65,14,816$ & $28.70 \%$ & $100.00 \%$ \\
\hline
\end{tabular}

Adapted from Internet World Stats( 2010) .

Journal of Technology Management for Growing Economies, Volume 2, Number 1, April 2011 
Table 2: Users of Internet in India in 2010

\begin{tabular}{|c|c|c|ccc|}
\hline Region & $\begin{array}{c}\text { Population } \\
(2010)\end{array}$ & $\begin{array}{c}\text { Percentage } \\
\text { population } \\
\text { of the world }\end{array}$ & $\begin{array}{c}\text { Internet } \\
\text { users till } \\
\text { June } 2010\end{array}$ & $\begin{array}{c}\text { Penetration of } \\
\text { internet }\end{array}$ & $\begin{array}{c}\text { Unternet } \\
\text { percentage } \\
\text { of the world }\end{array}$ \\
\hline India & $1,17,31,08,018$ & $17.13 \%$ & $8,10,00,000$ & $6.90 \%$ & $4.12 \%$ \\
\hline
\end{tabular}

Adapted from Internet World Stats( 2010) ${ }^{B}$
Synergy between Internet Technology

Table 3: Internet penetration and population density in India and Asia

\begin{tabular}{|l|l|l|l|l|l|}
\hline $\begin{array}{l}\text { Population } \\
\text { Density-India } \\
\text { (Approx) }\end{array}$ & $\begin{array}{l}\text { Population } \\
\text { Density-Asia } \\
\text { (Approx) }\end{array}$ & $\begin{array}{l}\text { Internet } \\
\text { penetration- } \\
\text { India } \\
\text { thenearest decimal) }\end{array}$ & $\begin{array}{l}\text { Internet } \\
\text { penetration- } \\
\text { Asia (Rounded to } \\
\text { the nearest decimal) }\end{array}$ & $\begin{array}{l}\text { People using } \\
\text { the net per sq } \\
\text { kilometer-India }\end{array}$ & $\begin{array}{l}\text { People using } \\
\text { the net per sq } \\
\text { kilometer- } \\
\text { Asia }\end{array}$ \\
\hline 356 per sq km & 86 per sq km & $7 \%$ & $22 \%$ & 25 (approx) & 19 (approx) \\
\hline
\end{tabular}

Date Sources: CIA( 2010), Encyclopedia (2010), Internet World Stats( 2010)B , Internet World Stats (2010) ${ }^{C}$

Table 1 and 2 highlight that Internet's penetration in India has risen to 7\% while in Asia, Internet's penetration is about $17 \%$ and world over the medium is used by $29 \%$ of the world population. Though the penetration numbers in India are marginal as compared to Asia and the World, it is still a positive indication to the marketers because India is the second most populous country of the world (CIA, 2010) and 7\% penetration of Internet also translates into 81 million users in the country. It is essential to consider the population density of the country with the continent to figure out whether the penetration must be considered low or high. Table 3 reveals that in India about 25 people, per square kilometer, are Internet users while in Asia about 19 people are Internet users (per sq $\mathrm{km}$ ). It is evident that Internet in India has limited reach but marketers cannot afford to ignore the medium because it reaches those 25 people per square kilometer, who are mostly literate and $69 \%$ of them belong to Socio-Economic Category A and B. $57 \%$ of these users are either college goers or men between the age group of 21- 35 yrs whose purpose of using the medium is primarily for e-mailing $(91 \%)$, general information search $(76 \%)$, education information search (49\%), text chat (46\%) and online gaming (41\%) (e-Tech, IMRB and IAMAI 2008). Obviously marketers wish to target this potential consumer base on the Internet and they do so through search -engine optimization, various display advertisements, pop up ads on e-mail pages, mailers on product/ service information and brands integrated within the theme of a game (Crazy 
Rishi, M.

Taxi has a tie-up with KFC, Kentenky's Fried Chicken and McDonalds). The data also brings out the scope for marketers to explore Internet's strength furthermore and for the government and Internet technology enablers to expand the reach of the medium.

\section{INTERNET ADVERTISING AND INDIAN MARKETERS}

Current study reveals that Indian marketers have started to accept Internet as an advertising medium; however the medium has been unable to garner complete trust from the advertising fraternity. Table 4 highlights that the combination of the media, Television, Print and Internet, attracts maximum faith from marketers and 60\% Indian advertisers/ marketers prefer to advertise about their offerings through this media mix. Clearly advertising campaigns, from the marketers' perspective are moving towards a synergy between the traditional media and the Internet.

Table 4: Media preferences amongst Indian Advertising fraternity

\begin{tabular}{|l|c|c|c|c|c|c|}
\hline & $\begin{array}{c}\text { Television- } \\
\text { Print-Radio }\end{array}$ & $\begin{array}{c}\text { Television- } \\
\text { Print- } \\
\text { Outdoor }\end{array}$ & $\begin{array}{c}\text { Television- } \\
\text { Print- } \\
\text { Internet }\end{array}$ & $\begin{array}{c}\text { Only } \\
\text { Internet }\end{array}$ & $\begin{array}{c}\text { Only } \\
\text { Television } \\
\text { OR Only } \\
\text { Print }\end{array}$ & $\begin{array}{c}\text { Television- } \\
\text { Print-Cinema }\end{array}$ \\
\hline $\begin{array}{l}\text { Marketers } \\
\text { Rank I (No of } \\
\text { respondents) }\end{array}$ & 10 & 10 & 41 & 0 & 4 & 4 \\
\hline Percentage & $14 \%$ & $14 \%$ & $60 \%$ & 0 & $6 \%$ & $6 \%$ \\
\hline $\begin{array}{l}\text { Agency } \\
\text { professionals } \\
\begin{array}{l}\text { Rank I (No of } \\
\text { respondents) }\end{array}\end{array}$ & 15 & 16 & 16 & 0 & 0 & \\
\hline Percentage & $30 \%$ & $32 \%$ & $32 \%$ & 0 & 0 & $6 \%$ \\
\hline
\end{tabular}

Table 4 shows that 'Only Internet' as an advertising medium strikingly got zero responses from marketers while 'Only Television or Only Print' was chosen by $6 \%$ respondents. This indicates that the Indian market is largely uncomfortable about the concept of running an advertising campaign in a singular medium and the adoption of Internet Technology, exclusively, is even more radical for Indian marketers. However Internet advertising is preferred in the media mix for advertising campaigns when Internet is combined with other traditional media as $60 \%$ of Indian marketers prefer to advertise simultaneously in Television-Print and Internet. Marketers consider this media mix as an efficient choice to attain brand recognition, recall and achieve the advertising objective because the advertising fraternity is aiming at creating a targeted impact through the new, technology driven media, along with leveraging the potency of conventional advertising patterns through the traditional media. 
An important basis for Internet advertising being preferred only with a Synergy between combination of campaigns on other traditional media derives from the Interactivity element of Internet. Traditional media hold lower perceived risk for advertisers since these media are established and recurrently advertised on. However, Internet is also gaining popularity because it has a unique feature of interactivity. Audiences are passive recipients of advertisements in case of TV, Print and Outdoor hoardings but in case of Internet advertising, a consumer must be motivated and interested in the advertisement to click on it and gather information from it (Menon and Soman, 2002; Faber et al., 2004; Aziz et al., 2008). Features like live chat support for advertised brands adds to the interactivity element of the medium. When this is combined with the advertising on traditional media, it makes the total brand campaign more effective. Since Internet Advertising contributes $3.5 \%$ to the total Indian advertising pie, as compared to Print that contributes $46.8 \%$ and Television that holds a share of $39.9 \%$ (KPMG and FICCI, 2010), it is clear that the medium offers relatively clutter free advertising as compared to traditional media. Television and Print are flooded with plethora of advertisements and each advertised brand wants to claim its share of the audiences' attention. Internet, however, offers the advertisers a chance of eye-ball-contact with the right audiences with an opportunity to place their brand in an advertising environment that has lesser competitors in the same space.

Internet technology also offers other distinguishing strengths and when these are clubbed with the security, branding capability and high penetration of conventional media, then an advertising campaign spread between the new medium as well as the traditional media, seems a prudent decision for advertisers. Some of these strengths include Internet's ability of exact targeting to an audience spread globally through advertising solutions that are cost effective and capable of not just building the brand but also generating customer leads of the marketer (Yaveroglu and Donthu, 2008, GroupM, 2008, Boudreau and Watson 2006).

Internet advertising facilitates exact targeting by helping advertisers in reaching the right audience at the right time with the right product, by evaluating the demand and activities' pattern that they demonstrate on the Internet. This is aided through the 'cookie technology'. Cookies are "small files stored on the customers hard disk that allow the client side browser to be tagged with a unique identifier"(Chatterjee et al., 2003). Advertisers are able to track the customers' pattern of browsing on the Internet and hence, target them with display advertisements on the most frequented website, at the most appropriate time, ensuring that the advertising effort is

Journal of Technology Management for Growing Economies, Volume 2, Number 1, April 2011 
Rishi, M. highly beneficial to the marketer (Yaveroglu and Donthu, 2008). Also, Internet uniquely facilitates marketers in targeting SEC A and SEC B of the society( who hold the maximum purchasing power) because about $61 \%$ Internet users in India, belong to the top 8 metros and small metros and $72 \%$ of the users fall in the SEC A and B categories( IAMAI and IMRB, 2007). To add to the marketers' advantage, advertising on the medium helps in garnering better Return on Investment and is cost effective. An advertiser pays much more on TV, Radio, Print etc while Internet is the only medium that allows the marketers to run a campaign on price models like Cost-Per-Click and Cost-Per-Lead (Group M, 2008). Taking this view to explore the medium's combination with traditional media, it is clear that through Internet advertising, the marketer can reach a target group that has the purchasing capacity and can be tracked through their browsing behaviour at the most appropriate time. Hence advertisers get a chance to continue with their campaign on traditional media and at the same time explore the strength of Internet advertising without having to work on large budgets to do so. Moreover, advertisers like to harp on the brand building aspects of the conventional media and lead generation benefits offered by Internet, together in a single advertising campaign. This means that marketers expect that the audience clicks on the banner/ display advertisement on Internet so that the webpage gets forwarded towards the advertiser's website where users share their contact information and express interest in being contacted. Internet technology hence allows advertising with an element of performance measurement and ad-testing because of the availability of Click Through Rates, which help in identifying the number of times the advertisement has been viewed on a particular website (Ling et al, 1999).

Considering all these potential benefit of Internet, marketers are slowly encouraged to advertise on the new medium but with its penetration lower than traditional media, it is observable that advertisers are unable to invest their trust in the efficacy of the new medium in totality. Table 5 shows that $78 \%$ Indian marketers are unsure about the efficacy of Internet Technology as a potential advertising medium, that could achieve advertising objectives, while $22 \%$ marketers hold reservations about the medium based on it's low penetration in India. Coupled with shallow penetration, the medium also suffers from the phenomenon of lower time spent on it's usage. Active Internet users in India spent around 9.3 hours per week using the medium (e-Tech, IMRB and IAMAI, 2008) in the year 2008 while consumption of traditional media like TV, is a very dominant pastime amongst media audiences across the world (Warc, 2010). These

Journal of Technology Management for Growing Economies, Volume 2, Number 1, April 2011 
statistics are also responsible for the medium being a choice for advertising primarily in tandem with the traditional media like television and print.
Synergy between Internet Technology

Table 5: Reservations about Internet

\begin{tabular}{|l|l|l|}
\hline & \multicolumn{1}{|c|}{$\begin{array}{l}\text { Low } \\
\text { Penetration }\end{array}$} & $\begin{array}{c}\text { Unsure about } \\
\text { medium's } \\
\text { effectiveness }\end{array}$ \\
\hline Marketers & $15(22 \%)$ & $54(78 \%)$ \\
\hline Agency & $23(40 \%)$ & $27(54 \%)$ \\
\hline
\end{tabular}

\section{INTERNET ADVERTISINGAND INDIAN ADVERTISING AGENCIES}

Professionals in the Indian advertising agencies however opine differently from Indian marketers and take a more neutral stand while deciding any campaign's media mix. Table 4 shows that $62 \%$ agency professionals prefer the combination of conventional media mix like Television-PrintRadio and Television-Print-Outdoor while 32\% suggest Television-PrintInternet to their clients (advertisers). Rajanish ( 2007), Head-Microsoft Advertising Solutions, claims that, in isolation, online advertising would never survive and only when a synergy is drawn between different media effectively the specific responsibility of each medium towards the overall campaign, would get fulfilled. He further pin points that Internet unlike other traditional media does not have a formal and authentic methodology to project the number of users in India. Due to this, advertisers and marketers cannot be given real time figures of the number of audiences who would be exposed to their advertisement on a given website. Research agencies like ComScore and JuxtConsult present user numbers, which are trusted within the industry, however these are also not completely representative of the total population of users. Advertisers hence have to rely primarily on their "gut- feel" about the medium's effectiveness and hence they end up investing in the wrong technique given the kind of product category that they are dealing in (Coremetrics, 2008). If such a campaign then fails, it leads to discouragement in terms of the use of the medium for the purpose of advertising. It is evident that agency professionals hold a cautious and reserved view of Internet advertising and are hesitant to suggest the same to marketers who are "Risk-Averse" (Ling et. al, 1999). This phenomenon slows down the progress of Internet advertising in India because marketers look at agencies as a platform where various advertising options are scanned and the best suited media mix is decided by experienced agency professionals, who are trusted for their advertising knowledge, by marketers. 
Rishi, M. Trehan (2007), Head NDTV Convergence, attributes the lack of understanding of the medium to be a key reservation about its usage for the purpose of advertising. He believes that from top management to the agencies who facilitate advertisers in buying space and time on the electronic medium, the understanding of the usage and efficacy of the medium remains a problem. This is because top level decision- makers as well as middle level managers do not fully understand the medium while media planners in advertising agencies like to take the more conventional or safer route by continuing to promote the traditional media. Swaroop (2008), Chief MentorDigital agency 'Smile Interactive', opines that one of the key limitations of Internet as a medium for advertising lies in its' inability to hold the attention span of the consumers and for creating a mass appeal of the medium, advertisers need to be equipped with sophisticated creative tools and techniques. This fact when coupled with the reservations of marketers, about Internet, acts as a deterrent in the choice of this medium in seclusion and when advertising agency professionals too, hold a watchful view of the medium, it leads to an advertising campaign that draws from the strengths of the conventional as well as the new medium simultaneously. Sharma (2010), Chairperson and CEO-Leo Burnett India, believes that the future of the digital medium is bright in India, however, marketers as well as agency professionals would only embrace it with more trust, when "flatrate-broadband" makes the penetration of Internet technology very deep in the country.

\section{CONCLUSION AND RECOMMENDATION}

The research results make is evident that Indian marketers and Indian advertising agency professionals hold apprehensions about Internet advertising however, marketers are ready to embrace the strengths of Internet technology more willingly while the agency professionals are extremely cautious about the new medium . Both the communities, however, unanimously believe that neither traditional media, nor Internet, are beneficial to an advertising campaign if they are advertised on, in seclusion. Synergy between the conventional and digital medium is the preferred media-mix choice amongst marketers and advertising agency professionals too, must embrace this change and propose newer, more creative concepts to advertisers, that could harness the strengths of the digital medium in totality. Marketers largely consider the medium's low penetration in India, as a deterrent for it being used for advertising while advertising agency professionals are affected in their view about Internet advertising, almost equally, by the medium's low penetration figures and the doubts about its efficacy in achieving advertising objectives.

Journal of Technology Management for Growing Economies, Volume 2, Number 1, April 2011 
It is recommended that media planners and marketers draw largely from

Synergy between the benefits of the synergy between traditional and new media by converging the same with mobile technology. In India, around $23 \%$ of Internet users, access the medium through mobile phones and since PC penetration is low in the country, mobile phones are looked at, as future access points of Internet (JuxtConsult, 2010). Since Smartphones have revolutionized the pattern of mobile usage, (Rishi and Singh, 2011) making Internet easily accessible through mobile devices, it is evident that creative concepts that can support Internet as well as mobile technology, simultaneously would be the key to Internet Technology achieve success through convergence. This would also lead to productive advertising that would be high on achieving results based on its omnipresent nature. Ling et. Al( 1999), too, in their study points out that Internet advertising would see a rise as and when more and more marketers would see their rivals advertise on the Internet and eventually, not being present on the Internet would prove fatal for the businesses of marketers. Like this, web advertising would gain popularity and the perceived risk associated with investment on Internet Advertising, would gradually reduce. Considering that maximum Internet users belong to SEC A and B, it is recommended that marketers belonging to education brands must utilise the medium to create awareness about their entities amongst the consume group. Since social interactivity and activities revolving around entertainment remain highly popular, on Internet (Juxt Consult, 2010), it would be prudent to amalgamate advertising initiative with the social media space, discussions, blogs, online game, e-mails and chat windows.

Finally, Internet technology, as a potential advertising tool has to be embraced, first, by advertising agency professionals, who in turn could promote the same to marketers. Marketers trust the advertising knowledge of agency professionals and the business of Internet advertising would grow faster when the medium's strengths are propagated by agencies to their clients in a more comprehendible manner. As a clan, the Indian marketers think positively about advertising on Internet by synergising the campaign with traditional, more established media, and this trend has to be utilised to the benefit of Internet advertising, by Indian advertising agency professionals.

\section{REFERENCES}

Aziz, N. A., Yasin, N.M.. and Kadir, S.L.S.A. (2008), 'Web Advertising Beliefs and Attitude: Internet Users' View', The Business Review, Cambridge, 9:2, 332.

Boudreau, M.C. and Watson, R.T.W. (2006), 'Internet Advertising Strategy Alignment', Internet Research, 16: 1, 23.

Chatterjee, P., Hoffman, D.L. and Novak, T. P. (2003) 'Modeling the Clickstream: Implications for web based advertising efforts', Marketing Science, 22:4, 520.

Journal of Technology Management for Growing Economies, Volume 2, Number 1, April 2011 
Rishi, M. 100
CIA (2010) 'Central Intelligence Agency'(online) (cited on 27 ${ }^{\text {th }}$ October 2010). Available from <URL:https://www.cia.gov/library/publications/the-world-factbook/geos/in.html.>

Coremetrics (2008) Optimizing your marketing mix in a downturn economy, White Paper.

Encyclopedia (2010) (online) (cited on 27th October 2010). Available from <URL http:// www.encyclopedia.com/topic/Asia.aspx.>

E-Tech, IMRB and IAMAI (Internet and Mobile Association of India) (2008) I-Cube, Mumbai.

Faber, R.J., Lee, M. and Nan, X. (2004) 'Advertising and the Consumer Information Environment Online', The American Behavioral Scientist, 48:4, 447

Fam, K.S., Waller, D.S. and Henry, J. (2007) 'Effects and Future of the Internet on the Malaysian advertising Industry', International Journal of Business and Society, 8:2, 13.

Group M (2008) This Year, Next Year: India Media Forecasts, April.

Hairong, L. and John, D.L. (2004) 'Internet Advertising Formats and Effectiveness, an invited chapter for Thorson \& Schumann' (online) (cited on $28^{\text {th }}$ November 2010). Available from <URL:http://www.ciadvertising.org/studies/reports/measurement/ad_format_print.pdf>

Hoy, M.G.and Lwin, M.O. (2008) 'An International Perspective of Online Disclosure Presentation: A comparision of Banner ad Disclosures from United States', United Kingdom and Singapore websites, Springer Science+Business Media.

IAMAI (Internet and Mobile Association of India) (2009) Online Display Advertising India, Mumbai, pp. 8.

IAMAI and IMRB International (2007) ' I-Cube 2007, Internet in India', 5th December, Report.

Idil, Y. and Naveen, D. (2008) 'Advertising placement and Ad placement issues in On-line environment', Journal of Advertising, 37:2, 31.

Internet World Stats (2010) (online) (cited 23 October 2010). Available from <URL:http:// internetworldstats.com/stats2.htm>.

Internet World Stats (2010) ${ }^{\mathrm{B}}$ (online) (cited 22 October 2010). Available from <URL:http:// internetworldstats.com/stats3.htm>.

Internet World Stats $(2010)^{\mathrm{C}}$ (online) (cited 27 October 2010). Available from <URL:http:// internetworldstats.com/stats.htm>

John, D.L. ( 2005) 'The Interaction of Traditional and New Media in Stafford, Marla L and Faber, Ronald J., Advertising, Promotion and New Media, New York, M.E. Sharpe Publishers, pp 4-27

JuxtConsult (2010), India Online Landscape 2010, Mumbai, India.

Kartik, P. and Hoon, L.J. (2003) 'Web banner ads in online newspapers: a cross national comparison of India and Korea', International Journal of Advertising, 22:4, 531-564

KPMG and FICCI (2010) 'Back in the Spotlight: FICCI-KPMG Indian Media and Entertainment Industry Report', India, pp. 152.

Marchus, L., Kevin, L., Norman, M. and Alfredo, M. (1999) 'Economics of advertising: Emerging function of Internet advertising', Netnomics: Economic Research and Electronic Networking, $1: 2,127$.

Meeker, M. (1997) The Internet Advertising Report, New York, Harper Collins, Chapter 3.

PWC and IAB (2010) IAB Internet Advertising Revenue Report: An Industry Survey conducted by PwC and sponsored by the Interactive Advertising Bureau (IAB), New York, USA.

Rajanish (2007) 'Net Compliments all other media formats, cited in Aggarwal, Deepthi, Pitch, 4:11, 116- 118.

Rishi, M. and Singh, A. (2011) 'Innovation in Mobile Applications: Emerging Trends' in Aggarwal, R, Khurana, R and Debnath, N.C. (eds.), 'Computing Business Applications and Legal Issues’, Excel Book, New Delhi, pp. 272-289. 
Satya, M. and Dilip, S. (2002) 'Managing the Power of Curiosity for Effective Web Advertising Strategies', Journal of Advertising, 31:3, 1-14.

Schweizer, K. (2010) Asia pacific to pass North America as biggest ad market in 2014 (online). (cited on 23rd September 2010) Available from <URL: http://www.bloomberg.com/news/ 2010-09-12/asia-pacific-to-pass-north-america-as-biggest-ad-market-in-2014.html>

Sharma, A. (2010) Chairperson and CEO, Leo Burnett India, I'm Glad we panicked in 2009 (online) (cited in Joshi, D., 12 October 2010). Available from (URL: http://www.afaqs.com/ advertising/interviews/index.html?id=332_Im+glad+we+panicked+in+2009>

Swaroop, M. (2008) 'Net must learn from old media,' published in Aggarwal Deepthi, Pitch, 5:11, $82-83$.

Trehan, S. (2007) 'NDTV Convergence'- 'News space is growing by the day,' published in Aggarwal, D., Pitch, 5:11, 125.

Warc (2010) 'Media Usage across the Globe' (online) (cited 7 November 2011). Available from <URL:http://www.warc.com/Search/WordSearch/Results.asp>

Meghna Rishi, Ph.D. Assistant Professor, Institute for International Management and Technology, Gurgaon, Haryana, India. She is on the editorial board of international and national refered journals and publishes in the area of Internet advertising, hospitality and tourism and strategic Marketing. 